\title{
Towards a New Solution Mechanism for Corporate Bankruptcy
}

\section{Omar Chaudry"}

\section{Introduction}

A firm may resort to leverage in its capital structure for a variety of reasons; to capture the benefits of the tax shield of debt, to signal to the market that it sees a bright future for itself, or as a commitment device to reduce financial slack. Unforeseen circumstances, however, may force the firm into a situation where it is unable to pay its debts. If the environment is such that the firm has a single creditor, emerging from a situation like this may not pose too much of a problem. However, problems are likely to arise if there are multiple creditors. A resource-wasting race is likely to ensue as the creditors try to "be first" to seize the firm's assets (in the case of a secured loan) or to obtain a judgement against the firm (in the case of an unsecured loan). This race may lead to a dismantling of the firm's assets, which may mean a loss in value if the firm is worth more as an entity than it is as a collection of pieces.

If such occurrences are common, debtors and creditors would certainly anticipate them while drawing up their initial contracts; it would then be reasonable to ask the question why they would not specify as part of their contracts a mechanism that would be triggered off in a state of default? If such an arrangement were possible, the state would not be required to provide a bankruptcy procedure.

The presence of transaction costs, which often prove to be too large for debtors and creditors, preclude them from designing such procedures; hence the reliance of the parties on a "standard form" bankruptcy procedure provided by the state. The role of a bankruptcy procedure is to ensure that the disposal of the assets of the distressed firm is carried out in a systematic manner.

Currently existing bankruptcy procedures in the West have undergone major criticism in the recent past, with both academics and practitioners expressing their discontent over them. Bankruptcy reform is being considered in the UK, France and the USA. Also, as the former centrally planned economies of Eastern Europe move towards capitalism, they have to make a choice about what form of bankruptcy code they will have to adopt, and this

\footnotetext{
${ }^{*}$ The author is Assistant Professor of Economics at the Lahore School of Economics.
} 
choice is by no means proving to be easy. Russia, for example has recently adopted a bankruptcy code which suffers from many of the problems that inflict such procedures in the West. Given the general discontent with bankruptcy procedures around the world, this paper attempts at ascertaining what a "good" bankruptcy procedure really is, and whether any such procedures are in existence. An alternative procedure is also suggested.

The rest of this paper is organised as follows. In section 2 , the goals of a good bankruptcy procedure are identified. In section 3, an overview of currently existing bankruptcy procedures is presented and some of the problems associated with each are highlighted. Section 4 is detailed analysis of an alternative procedure, due to Aghion, Hart, and Moore (AHM). In section 5 , an assessment of this procedure is made. Section 6 discusses some additional issues and some practical problems that may arise under the AHM procedure. Section 7 concludes.

\section{The Goals of a Good Bankruptcy Procedure}

From an economic theory standpoint, any "good" bankruptcy procedure should be focused towards the achievement of certain objectives, which are as follows.

First, the procedure should achieve an ex-post efficient outcome, the rationale for this goal being the fact that more is preferred to less, ceteris paribus. If a procedure differs from another only in that it results in more being available for everyone ex-post, then providing that the priority of claims is maintained, it will make everyone better off.

Second, it should give managers the right incentives to avoid bankruptcy. This goal is linked with the ex-ante bonding role of debt. Debt, it is argued, has an important role to play in constraining managers to act in the interests of claimholders. The importance of this role is much diminished if managers are not dealt with severely enough in the case of default on debt payments. Having reviewed the bankruptcy regime in the UK, a parliamentary commission wrote:

"It is a basic objective of the law to support the maintenance of commercial morality and encourage the fulfilment of financial obligations. Insolvency must not be an easy solution for those who can bear with equanimity the stigma of their own failure or the responsibility for the failure of a firm under their management." (Cork Report 1982, Chapter 4, at 191).

Third, it should result in an outcome that preserves the absolute priority of claims. If the priority of claims can be violated at will, then people 
may be reluctant to lend to the firm. Also, if the priority structure that is agreed to outside of bankruptcy is not enforced within it, then this may give certain parties incentives to bribe management to either cause bankruptcy or delay it, depending on how the party in question profits from the outcome.

Finally, the procedure should be one that puts the ultimate decisionmaking power in the hands of the claimants, rather than in the hands of an outside expert such as a bankruptcy judge, because it is the claimants who are affected by the outcome, and not the agent supervising the process.

We must, at this juncture, note that there are doubts about whether absolute priority should be maintained. It is argued that if equity-holders get little or nothing in a bankruptcy proceeding, then the management, acting in the equityholders' interests, will engage in highly risky investments when the firm is close to bankruptcy because, while the equityholders enjoy all the upside potential from the project, they bear very little of the downside risk; the creditors will lose if things go badly. However, to assume that management is really acting in the interests of the shareholders may well be an abstraction from reality in the case of large, widely held companies. They can safely be assumed to be self-interested in such circumstances. We may thus proceed further, armed with the notion that maintenance of absolute priority is indeed desirable.

Noteworthy is the point that some of the four goals may be in conflict. For example, the achievement of ex-post efficiency may dictate that the incumbent management be retained because it has certain firm-specific skills. This however, will conflict with the second goal because if the managers know that they will not be removed, then they may not have the correct ex-ante incentives to avoid bankruptcy. In such a situation, a good bankruptcy procedure would be one that strikes a reasonable balance between these goals.

\section{Existing Bankruptcy Procedures: an Overview}

Bankruptcy procedures can be classified as cash auctions, structured bargaining, administration, or automatic financial restructuring. Of these, the first three are procedures which are used in practice whereas the fourth is a theoretical possibility.

\subsection{Cash Auctions}

The firm's assets are sold, either piecemeal (in which case the firm is liquidated); or the firm is sold as a going concern. Either way, the receipts from the sale are distributed among the former claimants according to the 
absolute priority rule. The sale is supervised by a trustee or a supervisor. An example of a cash auction is Chapter 7 of the United States Bankruptcy Code or Liquidation in the United Kingdom.

A cash auction would be an efficient mechanism in a world of perfect capital markets. A potential bidder would be able to raise the necessary cash from a financial institution and make a bid for the distressed firm, with the aim of making it profitable again. Competition among bidders would ensure that the value-maximising outcome is achieved, i.e. that the firm is maintained as a going concern only if its continuation value is higher than its liquidation value.

In practice, however, capital markets are not perfect and this may result in a lack of competition in the auction and there may be few bids to keep the firm whole. Hence, we may see a disproportionately large number of liquidations at low prices. This imperfection in the capital markets thus reduces the efficacy of the cash auction solution to bankruptcy.

\subsection{Structured Bargaining}

Due to the growing scepticism about the cash auction alternative, another procedure that is commonplace is one that is based on the concept of structured bargaining. The underlying idea behind such a procedure is that the various claimants bargain about the distressed firm's future. The two issues that aim to be resolved through this process are deciding whether the firm should be shut down or continued, and how its value should be divided among the various claimants. The prime example of a structured bargaining process in the West is Chapter 11 of the US Bankruptcy Code. The process of Administration in the UK, as well as procedures in France, Germany and Japan are based on similar concepts.

Chapter 11 has been subject to a great deal of criticism in the last few years. It is felt that the process is time-consuming, costly, loss-inducing (to the firm in question), not harsh enough on incumbent management and that it mixes the decision of who should get what with what should happen to the firm. Moreover, as Chapter 11 places decisions in the hands of the supervising judge, it creates agency problems. A socially efficient level of resources is thus unlikely to be devoted to the achievement of a good reorganisation plan. Empirical findings suggest that Chapter 11 judges sometimes abuse their discretionary powers.

Two major problems inherent in any structured bargaining process deserve mention. First, restructured companies do not have an objective value. A proposal for overcoming this problem has been advocated by 
Bebchuk (1988) and will be explained in detail in section 4. Second, there is a danger that the wrong decision will be made concerning the firm's future. This is on account of the fact that voting mechanisms in most structured bargaining processes are fixed in advance; consequently, a situation may arise where people whose payoff should not be affected by the final outcome of the vote may end up controlling the pivotal votes. An example may help in clarifying the nature of this problem.

Scenario 1: Consider a firm that has entered bankruptcy. The firm owes its senior creditors $\$ 90$. It has been established that if the firm were to be shut down immediately and its assets sold off, it would be worth $£ 80$ (i.e. the liquidation value of the firm). However, if the firm were to be maintained as a going concern, it would be worth $£ 120$, on average. (If things go well, it would be worth $£ 170$; if they go badly, it would be worth $₫ 70$; the average is thus £120). The value-maximising choice is to keep the firm going, because $£ 120$ is greater than $£ 80$. If things go well, senior creditors get their full claim of $£ 90$, but if they do not go well, they get $£ 70$, which is less than the $£ 80$ liquidation value. So the senior creditors may vote to liquidate the firm. This is clearly the inefficient decision because if the firm is not liquidated, there would be enough value to pay off the senior creditors in full, and the junior creditors and shareholders would then vote, and make the efficient decision about the firm's future.

Scenario 2: The liquidation value of the firm, as before, is $£ 80$, as is the value of the senior creditors' claims (£90). However, the average going concern value of the firm is now only $\$ 70$ ( 1110 in the good state, $£ 30$ in the bad state).

The best possible outcome in the present situation is to liquidate the firm for $£ 80$. As this is less than the senior creditors' claim, the junior creditors and shareholders are not in the hands of the senior creditors, they would make the right decision about the firm's future.

It is very difficult for the various classes of claimants to bargain around these inefficiencies. As there are so many claimants, the negotiation process can become very lengthy and give rise to co-ordination problems within the various classes.

An agent (the administrator) is appointed, who decides, through the court, which parts of the firm should be sold off and which parts maintained as a going concern. The current French Bankruptcy System operates in this way, as did Chapter $\mathrm{X}$ of the old US Bankruptcy Code before 1978 . 
The merits of the administrative process in the UK are that it avoids many of the costs of US Chapter 11 and because the management of the distressed firm is no longer in charge, the process is not as soft on management as is US Chapter 11.

The major drawback with this procedure, however, is that it places a lot of power in the hands of the judge and the administrator, both of whom may not be suitably qualified, or possess the right incentives, to make either an accurate assessment of the prevailing conditions, or an efficient decision about the firm's future.

\subsection{Automatic Financial Restructuring}

This is an option that has not as yet been used in practice; it is merely a theoretical possibility. Some scholars suggest that financial distress should trigger off an automatic financial restructuring in a pre-specified manner, and the decision of what to do with the firm should then be left to the management.

The flaw with this system is that it ignores the conflict of interest between managers and shareholders. As managers enjoy private benefits of control, they will not want to shut down a firm, even if it is unprofitable. The bonding role of debt ceases to exist in a situation of this kind.

\section{An Alternative Regime: The Aghion-Hart-Moore Procedure}

When a firm enters bankruptcy and has to undergo a process of settlement of claims, the claimholders form a heterogeneous group, which inevitably leads to a lot of haggling.

The idea underlying the AHM procedure is to transform this heterogeneous group, i.e. with different claims, and therefore different objectives, into a homogeneous class of shareholders, which then decides through a process of voting, on the best alternative regarding the firm's future.

A practitioner is appointed to supervise the process that will ultimately take the firm out of bankruptcy. All the firm's debts are cancelled, the firm is converted into an all-equity firm, and a stay is put on the creditors' claims. A time period, usually of three to four months, is specified, within which this procedure is to be completed. There are two tasks confronting the practitioner. 


\section{Task 1}

He has to solicit bids, both cash and non-cash, for all or part of the new firm. For the bidding process to work well, the practitioner must ensure that bidders are provided with accurate information concerning the firm's prospects. A possible way to disseminate this information is to make sure that the bidders have access to the firm's books during the three-month period.

\section{Task 2}

He has to allocate rights to the equity in this new firm among the former claimholders.

The amount and priority of all claims is determined by the practitioner, employing some method outside our discussion.

\subsection{The framework}

Assume that, prior to bankruptcy, the firm had n classes of creditors.

Class 1 having the most senior claim, is owed $\mathrm{D}_{1}$.

Class 2 having the next most senior claim, is owed $\mathrm{D}_{2}$.

Class $\mathrm{n}$, having the most junior claim, is owed $\mathrm{D}_{\mathrm{n}}$

The claim of the shareholders is junior to all other claims, and they constitute the $(n+1)^{\text {th }}$ class.

Given this priority structure, the practitioner can proceed to allocate rights to equity in the new firm. What the share of each class of claimholders would be depends on whether the value of the new firm is objectively verifiable.

\subsubsection{When the value of the firm, $V$, is verifiable}

The agent will allocate rights based on absolute priority. Therefore, the most senior class of creditors, under this regime should get what it is owed, $\mathrm{D}_{1}$, or the entire value of the firm, $\mathrm{V}$, whichever is smaller. If $\mathrm{S}_{1}$ denotes the share of Class 1 creditors, then

\section{$\mathrm{S}_{1}=\min \left[\mathrm{D}_{1}, \mathrm{~V}\right]$}

Class 2 should similarly get what it is owed, or whatever is left over after class 1 has been paid off, i.e. 
$\mathrm{S}_{2}=\min \left[\mathrm{D}_{2}, \mathrm{~V}-\mathrm{S}_{1}\right]$

We can generalise this and obtain an expression for what class i will be entitled to under this scheme

$S_{i}=\min \left[D_{i}, V-S_{1}-S_{2}-\ldots \ldots \ldots . . . .-S_{i-1}\right]$

What about the equityholders? As this regime is one which preserves absolute priority, equityholders, being residual claimants, will get something only in the event that there is some value left over after all the creditors have been paid off. In that case, they will be entitled to

$\mathrm{S}_{\mathrm{n}+1}=\left[\mathrm{V}-\mathrm{S}_{1}-\mathrm{S}_{2}-\ldots \ldots . . . \mathrm{S}_{\mathrm{n}}\right]$

\subsubsection{When $V$ is not known}

In practice, $\mathrm{V}$ is seldom known. Given that the maintenance of absolute priority was identified as a desirable feature of a good bankruptcy procedure, how can the allocation of claims be consistent with it now that the value of the reorganised firm is not known?

Recourse has to be made to an ingenious scheme devised by Bebchuk (1988). The basic idea underlying the approach is as follows.

We know what the participants are entitled to as a function of the value of the reorganised firm, which itself we do not know. Based on this knowledge, it is possible to design and distribute to the participants, a set of rights concerning the units of the reorganised firm such that irrespective of the value that the reorganised firm takes, these rights would provide participants with values perfectly consistent with their entitlements. The way in which the scheme works is the following.

Class 1 creditors (the most senior class) are allocated 100 per cent of the firm's equity. A single creditor in this class receives $d_{1} / D_{1}$ of the firm's shares. The firm has a right to redeem this claim (buy back the equity) at a price of $\mathrm{D}_{1}$ per 100 per cent i.e. for the amount that this class is owed.

Class 2 creditors are given the option to buy the firm's equity at a price of $\mathrm{D}_{1}$ per 100 per cent; the firm has a right to redeem this claim at a price of $\mathrm{D}_{2}$ per 100 per cent, i.e. for the amount that this class is owed.

Class 3 creditors are given the option to buy equity at a price of $\left(\mathrm{D}_{1}+\mathrm{D}_{2}\right)$ per 100 per cent, with the firm having a right to redeem this claim at a price of $\mathrm{D}_{3}$ per 100 per cent. 
Generally speaking, class $\mathrm{i}$ creditors are given the option to buy equity at a price of $\left(\mathrm{D}_{1}+\mathrm{D}_{2}+\ldots \ldots+\mathrm{D}_{\mathrm{i}-1}\right)$ per 100 per cent; the firm has a right to redeem this claim at a price of $D_{i}$ per 100 per cent.

Finally, shareholders are given the option to buy equity at a price of $\left(\mathrm{D}_{1}+\ldots \ldots \ldots \ldots+\mathrm{D}_{\mathrm{n}}\right)$ per 100 per cent. This right is not redeemable by the firm.

After the rights have been allocated in the manner described above, the practitioner waits for the three-month period to lapse during which he collects all the incoming bids. At the end of the three-month period, he reveals all the bids to the claimholders in the new firm. The claimholders are then given an additional month to exercise their options (if they so wish), at the end of which the firm's future is put to a simple vote, and the firm exits bankruptcy.

The sequence of events is summarised below.

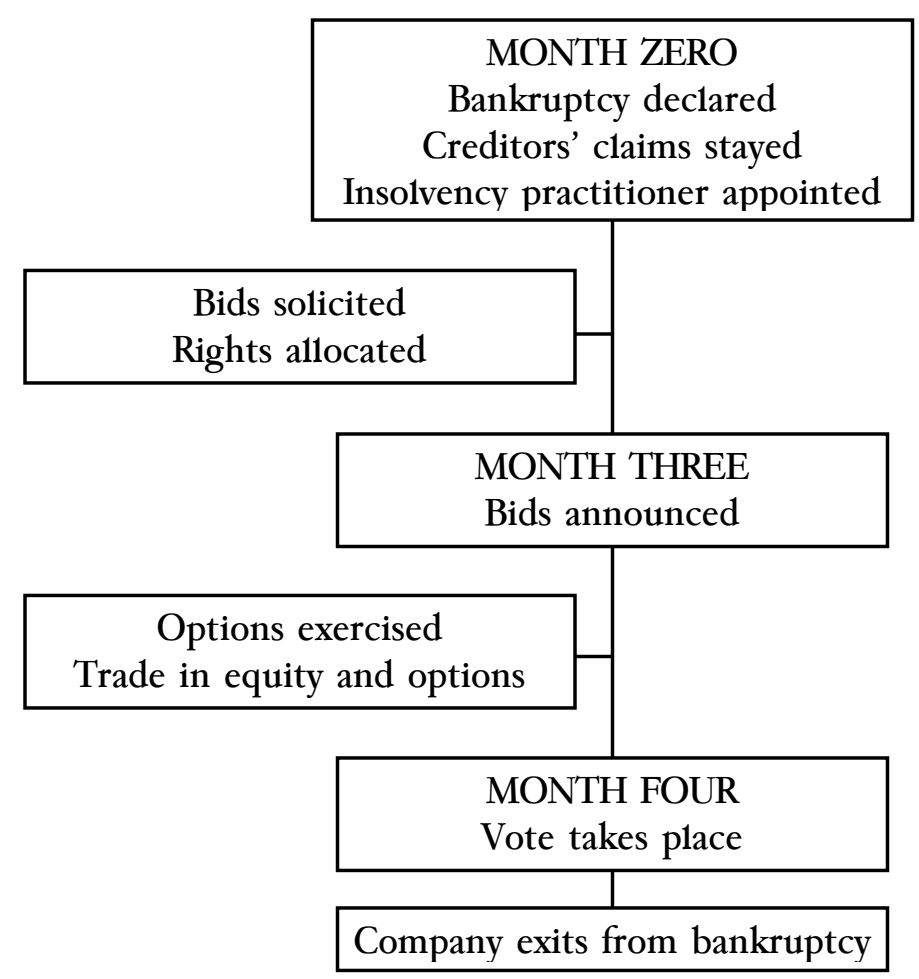

\subsection{Implementation of the procedure: an example}

We now consider with the help of an example how this procedure would be implemented. 
A bankrupt firm is composed of four classes of claimholders.

Class A consists of 100 senior creditors, each owed £1.

Class B consists of 100 intermediate creditors, each owed $£ 1$.

Class C consists of 100 junior creditors, each owed £1.

Class D consists of 100 equityholders, each holding one unit of equity.

After the firm is declared bankrupt, and a practitioner is appointed, the firm is divided into 100 equal units of equity. He will allocate rights to equity in the new firm as follows:

\subsubsection{Suppose the value of the reorganised firm is known}

The value of the firm is $\mathrm{V}$ per unit (of equity), which means that the total size of the reorganisation pie to be distributed is $100 \mathrm{~V}$. We consider four possible cases:

\section{Case 1}

$\mathrm{V}=0.8$, total value of the pie to be distributed $=80$

All units in the reorganised firm are given to the senior creditors, and divided among them pro rata. Therefore, each senior creditor gets 1 share in the new firm; the value of each share being $£ 0.80$.

Case 2

$\mathrm{V}=1.5$, total value of the pie to be distributed $=150$

Senior creditors get paid in full; they receive 100/1.5 units (each senior creditor receives 0.67 units). Intermediate creditors receive the remaining value, 100(1.5)-100; they get 100-100/1.5 units. Each one of them receives $1-1 / 1.5$ units. The junior creditors and the equityholders get nothing.

Case 3

$\mathrm{V}=2.5$, total value of the pie to be distributed $=250$

Senior creditors get $100(100 / 2.5$ units, or $1 / 2.5$ units each), intermediate creditors get $100(100 / 2.5$ units, or $1 / 2.5$ units each), and junior creditors get what is left over, i.e. 100(2.5)-200 (100-200/2.5 units, each getting 1-2/2.5 units each). The equityholders still get nothing. 


\section{Case 4}

$\mathrm{V}=3.5$, total value of the pie to be distributed $=350$

Senior creditors get $100(100 / 3.5$ units, or $1 / 3.5$ units each), intermediate creditors get $100(100 / 3.5$ units, or $1 / 3.5$ units each), junior creditors get $100(100 / 3.5$ units, or $1 / 3.5$ units each). The equityholders get the remaining value, which is $100(3.5)-300(100-300 / 3.5$ units, or 1$1 / 3.5$ units each)

The allocation of rights, it can be seen, is absolutely straightforward, when we know the value of the reorganised firm. The allocation is summarised in the table below.

Distribution of Units Supposing the value of the Reorganized Firm is known

\begin{tabular}{|c|c|c|}
\hline Value of $\mathrm{V}$ & Class of Claimant & Distribution of Units \\
\hline \multirow[t]{4}{*}{$\mathrm{V} \leq £ 1$} & Senior Creditors & 1 unit each \\
\hline & Intermediate Creditors & Nothing \\
\hline & Junior Creditors & Nothing \\
\hline & Equityholders & Nothing \\
\hline \multirow[t]{4}{*}{$£ 1<\mathrm{V} \leq £ 2$} & Senior Creditors & $1 / \mathrm{V}$ units each \\
\hline & Intermediate Creditors & $1-(1 / V)$ units each \\
\hline & Junior Creditors & Nothing \\
\hline & Equityholders & Nothing \\
\hline \multirow[t]{4}{*}{$\mathfrak{£} 2<\mathbf{V} \leq \mathfrak{\$} 3$} & Senior Creditors & $1 / \mathrm{V}$ units each \\
\hline & Intermediate Creditors & $1 / \mathrm{V}$ units each \\
\hline & Junior Creditors & $1-(2 / V)$ units each \\
\hline & Equityholders & Nothing \\
\hline \multirow[t]{4}{*}{$V>£ 3$} & Senior Creditors & $1 / \mathrm{V}$ units each \\
\hline & Intermediate Creditors & $1 / \mathrm{V}$ units each \\
\hline & Junior Creditors & $1 / \mathrm{V}$ units each \\
\hline & Equityholders & $1-(3 / V)$ units each \\
\hline
\end{tabular}




\subsubsection{When the value of the reorganised firm is not known}

Unfortunately, it is not common for $\mathrm{V}$ to be known and we have to allocate rights using some other method. In section 4.1 , we outlined the Bebchuk scheme. The scheme will now be used to allocate rights to the equity in the new firm.

The classes of the claimholders and the value of their claims is the same as in section 4.2.1. above. The allocation will be carried out as under.

Senior Creditors will receive one right each, which may be redeemed by the firm for $£ 1$ (in which case they will receive the full value of their claims), or in the event of it not being redeemed, will be entitled to receive one unit of equity in the reorganised firm.

Intermediate Creditors will receive one right each, which may be redeemed by the firm for £1 (in which case they will receive the full value of their claims), or in the event of it not being redeemed will have the option to purchase one unit of equity in the reorganised firm for $£ 1$.

Junior Creditors will receive one right each, which may be redeemed by the firm for $£ 1$ (in which case they will receive the full value of their claims), or in the event of it not being redeemed will have the option to purchase one unit of equity in the reorganised firm for $£ 2$.

Equityholders will receive one right each, which may not be redeemed by the firm. They will have an option to buy one unit of equity in the reorganised firm for $£ 3$.

The entitlements of the claimholders, as a function of the value of the reorganised firm are summarised in the table below.

\section{Claimholders' Entitlements when the value of the Reorganised Firm is not known}

\begin{tabular}{lcccc}
\hline & $\mathrm{V} \leq £ 1$ & $£ 1<\mathrm{V} \leq £ 2$ & $£ 2<\mathrm{V} \leq £ 3$ & $\mathrm{~V}>£ 3$ \\
\hline Senior Creditor & $\mathrm{V}$ & $£ 1$ & $£ 1$ & $£ 1$ \\
Intermediate & 0 & $\mathrm{~V}-£ 1$ & $£ 1$ & $£ 1$ \\
Creditor & & & & \\
Junior Creditor & 0 & 0 & $\mathrm{~V}-£ 2$ & $£ 1$ \\
Equityholder & 0 & 0 & 0 & $\mathrm{~V}-£ 3$ \\
\multicolumn{1}{c}{ TOTAL } & $\mathrm{V}$ & $\mathrm{V}$ & $\mathrm{V}$ & $\mathrm{V}$ \\
\hline
\end{tabular}


After the rights have been allocated and the three month period is over, the options will be exercised (or expire unexercised), and the firm will start anew.

\subsection{No basis for complaint}

In this framework, no class of claimholder has any basis for complaining that it is getting less than what it is entitled to. To make an assertion to this effect, a particular claimholder is, in effect, suggesting that either claimholders above him or those below him are receiving more than their rightful share.

By the very mechanics of the scheme, claimholders below the "complainant" can only be getting anything if they pay in full the value of the claims of all the classes above them, including the complainant's own class. Hence the complaint is not justified.

Also, if the complainant exercises his option, he will automatically ensure that those above him do not receive more than the full value of their claims. The complaint once more is not justified.

\subsection{Cash constraints}

Note that an intermediate or a junior creditor may be cashconstrained and may thus not be able to exercise his option. What happens in such a situation? A possible recourse for him is to borrow short-term (using the equity as collateral), exercise his option, and then sell his equity at a profit. But if his creditors do not see a bright future for the firm, then he will not be able to borrow, and we will end up in a situation whereby more equity will be held by the former senior creditors than is warranted by the face value of their debt. However, unfair as this redistribution of firm value may seem, there is still no scope for ex-post bargaining, as claims have been homogenised, and the new equityholders should still vote for the best bid.

\section{An Assessment of the AHM Procedure}

\subsection{The procedure fulfils the objectives of a "good" bankruptcy procedure}

In section 2, we outlined some objectives that a good bankruptcy procedure is expected to achieve. To assess the procedure explained in the previous section, we can invoke these objectives to see if they are fulfilled. 
First of all the new shareholders, as owners of the reorganised firm, decide its future. Since they have an incentive to vote for an efficient outcome, we can expect a value-maximising outcome. Second, the option

scheme ensures that absolute priority is preserved, and that no class of claimant can justify a complaint that some other class of claimant is getting more than its rightful share. Third, the decision-making power is indeed in the hands of the claimants, not in the hands of an outside expert. Finally, although the procedure does preserve the ex-ante bonding role of debt, managers may be able to convince shareholders that they were not responsible for financial distress and that they should hence be allowed to retain their jobs.

\subsection{The procedure overcomes the major problems inherent in a structured bargaining scheme}

In section 3, we saw that there were two problems associated with a structured bargaining process. The resolution of the first of these was explained in section 4, when we discussed the Bebchuk scheme. We now see how the AHM overcomes the second of these problems.

In Scenario 1, the available alternatives were to liquidate for $£ 80$ or continue for $£ 120$, and there was the possibility of an inefficient decision being made. Circumstances, now are different because the former creditors are shareholders, and they will want, through voting, to keep the firm going, since they enjoy all of the potential upside gains from continuation. Former shareholders will exercise their options by spending 0.9 and will get a share worth 1.2. The former senior creditors' claims have been met in full by the former shareholders, and the former shareholders will then vote for a continuation of the firm.

In Scenario 2, the two available alternatives were to liquidate for $£ 80$ or to continue for $£ 70$, and it was argued that the shareholders may have inefficiently kept the firm going by preventing a liquidation. Under the present setup, however, the shareholders' options will expire unexercised, (as spending 0.9 will only get them a share worth 0.8 at best) and the former senior creditors, who are now the shareholders in this new firm, will vote for a liquidation and close down the firm.

The final outcome in both cases is the value-maximising choice.

\subsection{Other Merits}

The AHM procedure has a number of other strengths, which can be summarised as follows. 
- By allowing both liquidation and recapitalisation/reorganisation, it presents a set of alternatives that encompasses all the options currently available under both Chapters 7 and 11 .

- We are aware of the fact that cash auctions may not be the best method around if raising cash for a bid proves to be a problem. The AHM procedure, to a great extent, mitigates this problem by allowing noncash bids.

- In Section 3, when automatic financial restructuring was proposed as a possible scheme, it was noted that incumbent management would be left in place unless and until it was removed. Under the AHM procedure, however, no one has the right to manage the firm unless voted in by the (new) shareholders in the reorganised firm. By not favouring the incumbent management within bankruptcy, the ex-ante bonding role of debt is preserved.

\section{Additional Issues}

In this section some issues that may arise with regard to the implementation of the AHM procedure are considered.

\subsection{Establishment of claims}

Neither AHM nor Bebchuk discuss any method by which the sizes and priorities of creditors' claims are to be established. They focus solely on the issue of reorganisation. Bebchuk admits that this process may be complex and time-consuming, and that it is only after the claims have been identified that the division process will proceed in an unimpeded manner.

\subsection{Claims disputes}

Given that disputes may arise while identifying claims, is the proposed period of 3 months not too short to allocate shares and options? AHM propose that as long as a reasonable proportion of the claims can be established within the three months, the claims that are established should be taken, shares and options should be allocated on the basis of these claims alone, the vote should be carried out, and the firm should emerge from bankruptcy with the contentious claims still outstanding.

\subsection{Voting procedures}

When the new claimholders in the reorganised firm vote on the future of the firm, then, in the case where there are two bids, the procedure is easy ...vote for the higher one. If, however, there are more 
than two, then the claimholders will have to arrive at a particular decisionmaking rule with regard to which bid to accept. However, difficulties normally encountered in voting theory are less likely to arise because of the common objective of value maximisation.

\subsection{Partial bids}

The AHM procedure assumes that the bids that are received in the three-month period are bids for the entire firm. However, this may not be the case. If partial bids are received, then it is up to the practitioner to deal with overlapping/inconsistent bids and assemble a menu of options to present to the claimholders. This may be a messy issue to confront.

\section{Concluding Remarks}

Though it is widely believed that capital markets are imperfect, the magnitude of the imperfections, however, remains an issue over which there is a considerable amount of disagreement. While some believe in the negligible nature of these imperfections, and hence consider perfect capital markets to be a reasonable approximation of reality, others believe that these imperfections are significant. In order for a bankruptcy procedure to gain universal acceptability, therefore, it must work well whether or not capital markets are perfect. The virtue of the proposed procedure is that it works well, irrespective of conditions, i.e. in perfect as well as in imperfect capital markets.

The proposed AHM procedure, if implemented, is one that would meet the criteria of a "good" bankruptcy procedure, lead to a valuemaximising capital structure for the firm, and bring about a significant reduction in the costs associated with reorganisation. 
Omar Chaudry 35

\section{References}

Aghion, P., Hart, O., and Moore, J., 1992. 'The Economics of Bankruptcy Reform'. Journal of Law, Economics and Organization, 8:523-46.

Aghion, P., Hart, O., and Moore, J., 1993. 'A Proposal for Bankruptcy Reform in the UK'. LSE Financial Markets Group Discussion Paper 167.

Aghion, P., Hart, O., and Moore, J., 1994. 'Improving Bankruptcy Procedure'. Washington University Law Quarterly, 72:811-827.

Bebchuk, L.A., 1988. 'A New Approach to Corporate Reorganizations'. Harvard Law Review, 101:775-804.

Franks, J., and Torous, W., 1992. 'Lessons from a Comparison of US and UK Insolvency Codes'. Oxford Review of Economic Policy, 8:70-82.

Gale, D., and Hellwig, M., 1985. 'Incentive Compatible Debt Contracts: The One-Period Problem'. Review of Economic Studies, 52:647-63.

Gertner, R., and Scharfstein, D., 1991. 'A Theory of Workouts and the Effects of Reorganization Law'. Journal of Finance, 46:1189-1222.

Hart, O., La Porta Drago, R., Lopez-de-Silanes, F., and Moore, J., 1996. 'A New Bankruptcy Procedure that Uses Multiple Auctions'. LSE STICERD Discussion Paper 312.

Warner, J., 1977. 'Bankruptcy Costs: Some Evidence'. Journal of Finance, $32: 337-47$.

Webb, D., 1991. 'An Economic Evaluation of Insolvency Procedures in the United Kingdom: Does the 1986 Insolvency Act Satisfy the Creditors' Bargain?’ Oxford Economic Papers, 43:139-157.

Weiss, L., 1990. 'Bankruptcy Resolution: Direct Costs and Violation of Absolute Priority'. Journal of Financial Economics, 27:285-314. 